\title{
치과용 $\mathrm{Ni}-\mathrm{Cr}$ 합금의 조성에 따른 세라믹의 색차 분석
}

\author{
김사임1 , 김태연 ${ }^{2}$, 김세하 ${ }^{2}$, 강정규 $^{3}$, 이정환 $^{3}$
}

1쎈 치과기공소, ${ }^{2}$ 전북대학교 치과대학 치과생체재료학교실, ${ }^{3}$ 광주보건대학교 치기공학과

\section{Ceramic color differences of dental $\mathrm{Ni}-\mathrm{Cr}$ alloy by compositional change}

\author{
Sa-Im Kim², Tae-Yeon Kim², Se-Ha Kim², Jeong-Gyu Kang ${ }^{3}$, Jung-Hwan Lee ${ }^{3}$ \\ ${ }^{1}$ SSen Dental Laboratory, Gwangju, Korea \\ ${ }^{2}$ Department of Dental Biomaterials and Institute of Biodegradable Material, School of Dentistry, Jeonbuk National University, Jeonju, Korea \\ ${ }^{3}$ Department of Dental Laboratory Technology, Gwangju Health University, Gwangju, Korea
}

\section{Article Info}

Received November 1, 2021

Revised December 10, 2021

Accepted December 21, 2021

\section{Corresponding Author}

Jung-Hwan Lee

Department of Dental Laboratory Technology, Gwangju Health University, 73 Bungmun Dae-ro 419 Beongil, Gwangsan-gu, Gwangju 62287, Korea

E-mail: leejh@ghc.ac.kr https://orcid.org/0000-0002-2065-5632

*This paper was supported by 2019

research fund offered from Gwangju Health University.

\begin{abstract}
Purpose: This study was conducted to investigate alloys spectrophotometrically including yttrium of nickel-chromium (Ni-Cr) alloys, which are used as substitutes for the regulation of beryllium and provide helpful improvements in Ni-Cr alloys.
\end{abstract}

Methods: Four groups of specimens (ZN, ZY, SN and EM) were prepared for analysis. Color parameters were measured with a spectrophotometer, and color difference $\left(\Delta \mathrm{E}^{*}\right)$ was calculated. The t-test and one-way analysis of variance test were used to determine significant difference, and the Tukey test was used to identify where the differences were. To measure the spectroscopic reflectivity, the spectroscopic reflectance was measured and converted into $\mathrm{CIE} L^{*}, a^{*}, b^{*}$ color system.

Results: The $\Delta \mathrm{E}^{*}$ value of each metal ceramic group after opaque firing of $\mathrm{Ni}-\mathrm{Cr}$ alloy with and without yttrium was $<2$, and the total group color difference $\left(\Delta E^{*}\right)$ was below 1 in the dentin ceramic all experimental group. However, the $a *$ and $b *$ values of the metal ceramic groups were higher than that in the lithium disilicate all ceramic group, and the chroma was higher than the natural tooth. The brightness of all experimental groups was similar to that of the shade guide sample.

Conclusion: Yttrium added to Ni-Cr alloys showed similar CIE $L^{*}, a^{*}, b^{*}$ values to $\mathrm{Ni}-\mathrm{Cr}$ alloys that did not contain yttrium, indicating that yttrium had no effect on color in metallic ceramic systems.

Key Words: Ni-Cr alloy, Yttrium, Spectrometer, Shade guide, Ceramic

\section{INTRODUCTION}

대한 환자들의 요구는 다양해지고 있으며, 자연치와 비슷한 색(color)과 형태(shape), 그리고 기능(function)을 최우선으로 한다. 이러한 환자들의 요구사항을 만족시키기 위해 장석류(feldspar) 세라믹은 자 연치아가 가지고 있는 심미와 기능, 형태를 재현하기 위한 재료로 가장 많이 사용되고 있으나, 굴곡강도가 60 70 Mpa 정도로 세라믹 자체만 으로 사용되기에는 취성이 매우 높아 파절 위험성의 단점이 있다. 세라 믹의 파절 위험성을 해결하기 위한 방법으로 금속하부 코어(core)를 사 용하는 이중구조 금속-세라믹관(porcelain fused to metal crown)이
개발되어 사용되고 있고, 심미성 향상을 목적으로 하는 지르코니아를 하부코어로 이용하는 지르코니아 이중구조 전부 세라믹관이 근래에 개 발되어 널리 사용되고 있다.

지르코니아 이중구조 전부 세라믹관은 하부 지르코니아 코어의 우수 한 생체 적합성이나 내식성, 금속코어에 비해 투명도가 높아 심미성이 우수하여 사용이 점차로 많아지고 있으나, 전장 세라믹과 하부 코어와 의 낮은 결합력과 인장력 그리고 미세구조 결함등으로 발생하는 전장 세라믹의 탈락(delaminetion) 파절양상이 단점으로 알려져 있고 임상 에서는 이중구조 형태의 보철물 제작 방식 보다는 투명도가 높은 지르 코니아를 computer-aided manufacturing (CAM) 가공하여 컬러링 
(coloring)을 하는 방식이 더 빈번하게 사용되고 있다. 전부 세라믹관 의 이러한 단점들로 금속-세라믹관은 아직까지 치과보철물의 많은 부 분을 차지하고있으며 전장 세라믹과의 높은 결합력과 금속 하부코어에 의한 강도 개선등의 장점을 가지고 있어 지속적으로 사용되고 있다[1]. 금속-세라믹관은 1950 년대 금 합금에 세라믹을 결합시키는 방법이 개 발되면서 현재까지 끊임없는 연구와 발전이 되어 오고 있으며[2], 최근 에는 computer-aided design (CAD)/CAM, selective laser melting과 같은 기술이 접목 되면서 많은 보철물 제작에 많은 발전이 이루 어졌다[3-5].

치과보철물에 대한 심미적 요구는 자연치와 유사한 형태와 색, 그리 고 기능을 포함한다. 자연치아 색은 법랑질과 상아질 그리고 형태 및 두께에 의해 차이가 나타나는데 이러한 자연치아의 색을 치과용 세라 믹으로 표현해 내기에는 치과기공사의 많은 노력이 필요하다. 이중구 조 금속-세라믹관이 구강 내에서 기능을 하기 위해 갖추어야 하는 자연 치와 유사한 심미성은 제한된 치아삭제량을 이용하여 하부 금속 코어 를 제작하고 금속의 색상을 효과적으로 차단하는 불투명 세라믹을 사 용한다. 일반적으로 전장 세라믹의 축성량이 많을수록 자연감을 얻을 수 있고 보철물의 적절한 해부학적 형태 재현을 위해서 일정량의 치아 삭제를 필요로 한다.

색은 보철물의 심미성에 영향을 미치는 요소이며 다양한 조건들에 의해 많은 차이가 나타나게 된다. 그 요소로는 하부코어의 종류, 투광 도, 세라믹 종류, 세라믹 두께, 술자의 색조 선택 능력, 진료실 조명, 사 용되는 shade guide 종류 등 다양한 조건들에 의해 영향을 받는다. 또 한 색조 결정은 보철물 제작에 많은 기공작업 기술적 요소들의 조합에 의해 이루어지며, 자연치아와 비슷한 색조 재현이 어려운 것은 이러한 요소들의 결과를 미리 측정할 수 없기 때문이다.

앞선 많은 연구에서 Dozić 등[6]과 Jalali 등[7]은 세라믹의 두께가 전부 세라믹 시스템의 최종 색상에 주는 영향을 발표하였고, Corciolani 등[8]은 세라믹의 두께가 금속-세라믹 시스템의 색 계수에 주는 영향에 관한 연구를 발표하였다. 또한 Stevenson과 Ibbetson [9]은 세라믹 비니어의 하부재료가 최종 수복물에 주는 영향을 발표하였고, Luthardt 등[10]은 세라믹 소성 횟수 및 opaque의 색채, Kelly 등[11] 은 하부 금속관과 합금의 종류에 관한 논문을 분석한 결과를 발표하였 다.

본 연구는 cobalt-chromium $(\mathrm{Co}-\mathrm{Cr})$ 합금에 비해 작업, 조정 및
마무리 과정이 용이한 장점이 있어서 많이 사용되어 왔던 $\mathrm{Ni}-\mathrm{Cr}$ 합금 의 성분 중, 합금 성능향상에 도움이 되었던 베릴륨 $(\mathrm{Be})$ 이 독성과 알러 지 반응과 같은 생물학적 문제로 인하여 사용이 규제되면서 이를 대체 하기 위한 방안으로 시작되었다. 현재 시판 되고 있는 $\mathrm{Ni}-\mathrm{Cr}$ 합금에 이 트륨(Y,yttrium)을 추가하여 합금을 조성하고 이트륨 포함 여부에 따 른 $\mathrm{Ni}-\mathrm{Cr}$ 합금과 전장 세라믹 간의 전단결합강도를 조사한 후속 연구 이다. 현재 베릴륨 사용이 금지된 $\mathrm{Ni}-\mathrm{Cr}$ 합금 사용 시 degassing 과정 과 세라믹 소성과정에서 발생되는 과도한 산화막 그리고 세라믹 균열 현상과 변색으로 인한 문제를 해결하기 위하여 현재 임상적으로 사용 되고 있는 $\mathrm{Ni}-\mathrm{Cr}$ 합금에 이트륨을 추가하고 이트륨 포함 여부에 따른 전장 세라믹의 색조 차이를 알아보고자 하였으며, 객관적인 측정을 위 해 분광반사율을 측정하여 CIE L*, $\mathrm{a}^{*}, \mathrm{~b}^{*}$ 색체계로 환산하는 분광측색 기(spectrophotometer)를 이용하여 비교분석 하였다.

\section{MATERIALS AND METHODS}

\section{1. 연구재료}

본 연구에서 실험한 재료는 시판되고 있는 $\mathrm{Ni}-\mathrm{Cr}$ 합금 중 $\mathrm{ZEROY}$ (Alpha Dent, Gwangju, Korea)와 StarLoy N (Dentsply Sirona, York, PA, USA)을 사용하였고 ZEROY Ni-Cr 합금에 이트륨을 추가 하여 ZEROY-Y 합금을 조성하였다. 금속 하부구조물의 색상을 차단하 기 위한 불투명 세라믹은 base paste opaque (Ceramco 3, Dentsply Sirona)와 색상을 결정지어 주는 shape opaque은 A3 paste opaque (Dentsply Sirona)가 사용되었으며 상아질 세라믹은 Ceramco 3의 A3 Dentin powder (Dentsply Sirona) 가 사용되었다(Table 1).

대조군으로 동일 색채를 표방하는 전부 세라믹 시편은 리튬 디실리 케이트 결정상을 강화한 글라스-세라믹 재료로 열 가압 성형을 하는 재 료인 IPS e.max Press (Ivoclar Vivadent, Schaan, Liechtenstein) 의 Ingot A3을 사용하였다.

\section{2. 시편제작}

\section{1) 치과용 주조합금 하부구조물 제작}

금속시편은 직경 $15 \mathrm{~mm}$, 두께 $0.8 \mathrm{~mm}$ 아크릴 원판을 이용하여 납 형을 제작한 뒤, 10 gauge round wax로 주입선을 부착하고 인산염계 매몰재(CB-30; Ticonium, Albany, NY, USA)를 사용하여 제조사 지

Table 1. Materials used in the study

\begin{tabular}{clcc}
\hline Group & Commercial name & Substructure & Opaque \\
\hline ZN & ZEROY & Ni-Cr alloy & Dentin \\
ZY & ZEROY-Y & Ni-Cr alloy & paste, A30 \\
SN & StarLoy N & Ni-Cr alloy & Base paste, A30 \\
EM & IPS e.max Press & Lithium disilicate glass-ceramic & B3 \\
A3 paste, A30 & A3 \\
\hline
\end{tabular}

ZN: ZEROY, ZY: ZEROY-Y, SN: StarLoy N, EM: IPS e.max Press, Ni-Cr: nickel-chromium. 
시대로 매몰한 뒤 주조하였고(n=36), 시편제작에 사용된 합금의 성분 은 Table 2 와 같다. 주조된 하부구조물은 $110 \mu \mathrm{m}$ 알루미늄 옥사이드 (Korox; Bego, Bremen, Germany)로 2 기압 하에서 약 $20 \mathrm{~mm}$ 떨 어져 30초간 공기분사연마(air abrasion)로 매몰재를 제거하고 초음파 세척 후 건조한 다음 주입선을 절삭(Vera disc, Shofu, Kyoto, Japan) 하고 증류수와 에탄올에 각각 10 분간 초음파 세척을 시행하였다.

\section{2) 세라믹 축성}

준비된 금속 시편은 표면 열처리를 위해 세라믹 소성로 (P301; Ivoclar Vivadent)에서 열처리를 시행한 후, 세라믹 축성을 위하여 제조 회사에서 추천하는 소성방법에 따라 축성하였다(Table 3). Base paste opaque는 1회 도포하고 A3 Shade opaque는 1회 도포하고 A3 Shade opaque 1회 소성한 다음(Fig. 1), 균일한 시편 제작을 위해 제 작된 몰드를 사용하여 Dentin A3로 시편을 제작하였다(Table 4). 소 결 후 금속-세라믹 시편의 표면을 \#400-\#2000번의 emery paper로 연마하여 시편의 두께가 균일하게 $1.2 \mathrm{~mm}$ 가 되도록 마무리 하고 self glazing을 시행하였다(Fig. 2).

\section{3. 측색방법}

시편의 색상 분석을 위해 제조사가 추전한 방법에 따라 한 사람의 검 사자가 모든 측색을 시행하였다. 색상 분석을 위한 광원은 CIE와 ISO 기준규격에서 표준 광원으로 사용되는 D65 광원을 이용하였고, 분광 측색기(VITA Easyshade V, VITA, Bad Säckingen, Germany)를 사 용하여 표준 백색판으로 영점을 조정한 다음 측정경에 시편을 밀착 시 켜 측정하였다. 금속-세라믹 시편과 전부 세라믹 리튬 디실리케이트 (lithium disilicate ceramic) 시편은 세라믹이 소성된 부위를 임의로 네 곳으로 나누어 CIE 표색계 L*, a*, b* 값을 측정하였으며 각 실험군 의 색상 차이인 $\Delta \mathrm{E}_{\mathrm{a}} \mathrm{b}$ 값을 계산하였다.

\section{4. 색차값 계산}

측색기에서 4회 측정한 평균값이 계산되어 나오면, 산술적 평균을 구하고 이 값을 이용하며 $\Delta \mathrm{E}^{*}$ 값을 계산하였고, 각 시편의 측정한 측색

Table 2. Composition of alloys

\begin{tabular}{|c|c|c|c|c|c|c|c|c|c|}
\hline \multirow{2}{*}{ Group } & \multicolumn{9}{|c|}{ Composition (wt\%) } \\
\hline & $\mathrm{Ni}$ & $\mathrm{Cr}$ & Mo & $\mathrm{Si}$ & $\mathrm{Al}$ & W & La & $Y$ & Bal. \\
\hline $\mathrm{ZN}$ & 66.0 & 20.0 & 5.0 & & 4.0 & & & & 2.0 \\
\hline$Z Y$ & 69.0 & 20.0 & 5.0 & & 4.0 & & & $\leq 2.0$ & \\
\hline SN & 61.0 & 25.8 & 11.0 & 1.5 & $<0.4$ & $<0.5$ & & & \\
\hline
\end{tabular}

ZN: ZEROY, ZY: ZEROY-Y, SN: StarLoy N, Ni: nickel, Cr: chromium, Mo: molybdenum, Si: silicon, Al: aluminuium, W: tungsten, La: lanthanum, Y: yttrium.

Table 3. Degassing firing schedule

\begin{tabular}{cccc}
\hline Pre-heating & Idle & Rate of rise & High-temperature \\
\hline $0 \mathrm{~min}$ & $500^{\circ} \mathrm{C}$ & $100^{\circ} \mathrm{C} / \mathrm{min}$ & $980^{\circ} \mathrm{C}$ \\
\hline
\end{tabular}

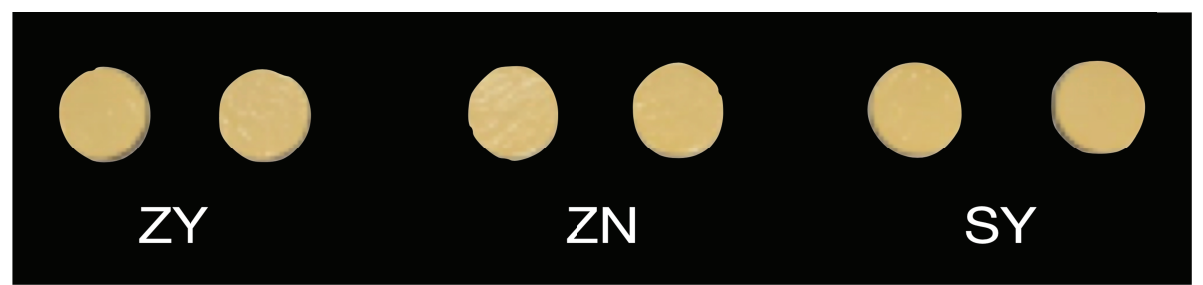

Figure 1. Substructure of opaque firing sample. (A) ZEROY-Y, (B) ZEROY, (C) StarLoy $\mathrm{N}$.

Table 4. Firing schedule of veneering materials used in this study

\begin{tabular}{|c|c|c|c|c|c|c|c|c|}
\hline \multirow{2}{*}{$\begin{array}{l}\text { Program } \\
\text { description }\end{array}$} & \multicolumn{3}{|c|}{ Time (min) } & \multicolumn{2}{|c|}{ Set-temperature ( $\left({ }^{\circ} \mathrm{C}\right)$} & \multicolumn{3}{|c|}{ Temperature $\left({ }^{\circ} \mathrm{C}\right)$} \\
\hline & Dry & Pre-heating & $\begin{array}{l}\text { High temperature } \\
\text { hold }\end{array}$ & Idle & $\begin{array}{l}\text { High- } \\
\text { temperature }\end{array}$ & Vac. start & Vac. stop & $\begin{array}{l}\text { Heat rate } \\
\text { ['C/min] }\end{array}$ \\
\hline Base paste & 5 & 3 & 0 & 500 & 975 & 500 & 975 & 100 \\
\hline Shape opaque & 5 & 5 & 0 & 500 & 970 & 500 & 970 & 100 \\
\hline Dentin powder & 5 & 5 & 0 & 650 & 960 & 650 & 960 & 55 \\
\hline
\end{tabular}

Vac.: Vacuum. 


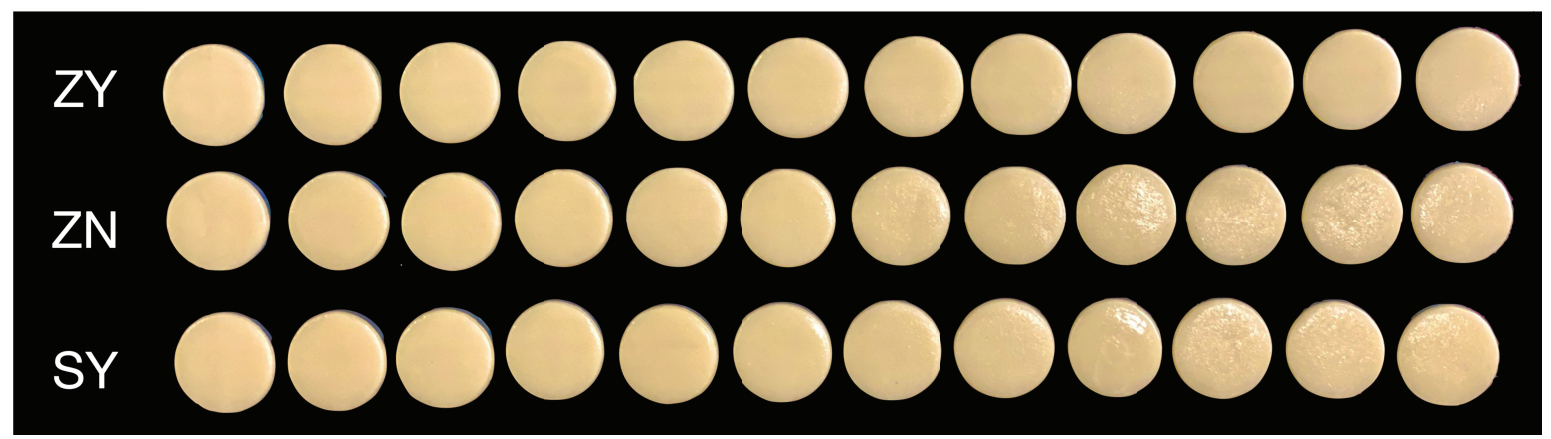

Figure 2. Veneering metal-ceramic samples. (A) ZEROY-Y, (B) ZEROY, (C) StarLoy N.

Table 5. Mean values of $L^{*}, a^{*}, b^{*}$ metal core groups and lithium disilicate glass ceramic group

\begin{tabular}{ccccc}
\hline \multicolumn{1}{c}{ Veneering materials } & Group & L*-value & a*-value & b*-value \\
\hline Dentin A3 & SN & $83.45(0.26)$ & $3.96(0.13)$ & $36.60(0.54)$ \\
& ZN & $84.19(0.27)$ & $4.07(0.10)$ & $37.32(0.27)$ \\
Lithium disilicate glass ceramic A3 & ZY & $84.68(0.28)$ & $4.03(0.08)$ & $37.37(0.41)$ \\
\hline
\end{tabular}

ZN: ZEROY, ZY: ZEROY-Y, SN: StarLoy N, EM: IPS e.max Press.

값 차이는 다음과 같은 공식을 이용하여 계산하였다.

$$
\begin{aligned}
& \Delta \mathrm{E}^{*}=\left\{\left(\Delta \mathrm{L}^{*}\right)^{2}+\left(\Delta \mathrm{a}^{*}\right)^{2}+\left(\Delta \mathrm{b}^{*}\right)^{2}\right\}^{1 / 2} \\
& \Delta \mathrm{L}^{*}=\mathrm{L}^{*}{ }_{1}-\mathrm{L}^{*}{ }_{2} \\
& \Delta \mathrm{a}^{*}=\mathrm{a}^{*}{ }_{1}-\mathrm{a}^{*}{ }_{2} \\
& \Delta \mathrm{b}^{*}=\mathrm{b}^{*}{ }_{1}-\mathrm{b}^{*}{ }_{2}
\end{aligned}
$$

\section{5. 통계 분석 방법}

통계는 SPSS ver. 12.0 (SPSS, Chicago, IL, USA)를 이용하여 분석 하였다. 금속 하부구조에 따른 각 실험군의 $\mathrm{L}^{*}, \mathrm{a}^{*}, \mathrm{~b}^{*}$ 값은 t-test를 이 용하여 유의차를 검정하였으며, 각 실험군간의 색조에 따른 $\Delta \mathrm{E}^{*}$ 값의 유의차를 검정하기 위해 일원배치 분산분석(one-way ANOVA)법을 이용하였고, Tukey honestly significant difference 검정을 통해 사 후분석을 시행하였다. 본 논문에서 사용된 모든 통계는 $95 \%$ 의 유의 수 준에서 검정되었다.

\section{RESULTS}

금속 세라믹 실험군과 리튬 디실리케이트 대조군 $\mathrm{L}^{*}, \mathrm{a}^{*}, \mathrm{~b}^{*}$ 측정값 은 Table 5 와 같다. $\mathrm{L}^{*}$ 은 명도를 나타내며 0 에서 100 까지의 수로 표 시한다. $a^{*}$ 는 적색-녹색 정도를 나타내는 지표이며 -60 부터 +80 까지 의 숫자로 표시하고 값이 클수록 적색, 값이 적을수록 녹색을 나타낸다. $\mathrm{b}^{*}$ 는 황색-청색 정도를 나타내는 지표로 범위는 -80 부터 +60 까지이며 값이 클수록 황색을 나타내고 값이 적을수록 청색을 나타낸다.

금속 세라믹 실험군의 경우 명도 값( $\left(\mathrm{L}^{*}\right)$ 은 83.45 84.68로 상호 유 사한 값을 보였고, 리튬 디실리케이트 실험군에서는 81.90으로 관찰
Table 6. Mean $\Delta \mathrm{E}_{\mathrm{ab}}$ values of specimens in combination metal core and Dentine $A 3$ groups

\begin{tabular}{ccc}
\hline Veneering materials & Between group & $\Delta$ E-value \\
\hline Dentin A3 & ZY-ZN & 0.12 \\
& ZY-SN & 1.05 \\
& ZN-SN & 0.53 \\
Dentin A3 - lithium & ZY-EM & 159.29 \\
disilicate glass & ZN-EM & 157.26 \\
ceramic A3 & SN-EM & 143.30 \\
\hline
\end{tabular}

ZN: ZEROY, ZY: ZEROY-Y, SN: StarLoy N, EM: IPS e.max Press.

되어 자연치 A3 색상 명도 값(L*) 75.36과 비교해 보면 약간의 차이 는 있었지만 유사하였다. $\mathrm{a}^{*}$ 측정값은 금속 세라믹 실험군과 리튬 디 실리케이트 실험군 모두에서 (+) 값을 보여 적색에 가까운 것을 보였는 데, 자연치에서 측정되는 $\mathrm{a}^{*}$ 측정값 1.36 과 비교해 보면 리틈 디실리 케이트 실험군의 값이 2.05로 가장 유사하였고, 금속 세라믹 실험군에 서는 3.96 4.07로 차이가 없었다. $b^{*}$ 측정값은 금속 세라믹 실험군에 서 36.60 37.37로 관찰되었고, 리튬 디실리케이트 글라스 세라믹 실 험군에서는 19.85로 관찰되었다(Table 5). 모든 실험군에서 $b^{*}$ 측정값 은 (+) 값으로 황색에 가까운 것을 보였으며, 자연치에서 측정되는 $b^{*}$ 측정값 19.61과 비교해 보면 리튬 디실리케이트 실험군의 값이 자연치 색상에 가장 유사하였으며, 불투명 세라믹 처리를 하는 금속 세라믹군 이 자연치 색상에 비해 보다 황색에 더 가까운 것을 알 수 있었다.

측정된 측색값의 평균과 표준 편차는 다음과 같다(Table 6). 모든 실 험군에서 명도는 통계적으로 유의한 차이가 나타나지 않았고, 금속 세 라믹 실험군과 리튬 디실리케이트 실험군에서 $a^{*}, b^{*}$ 값은 금속 하부구 조를 사용한 군에서 세라믹 하부구조를 사용한 군보다 높게 나타났으 


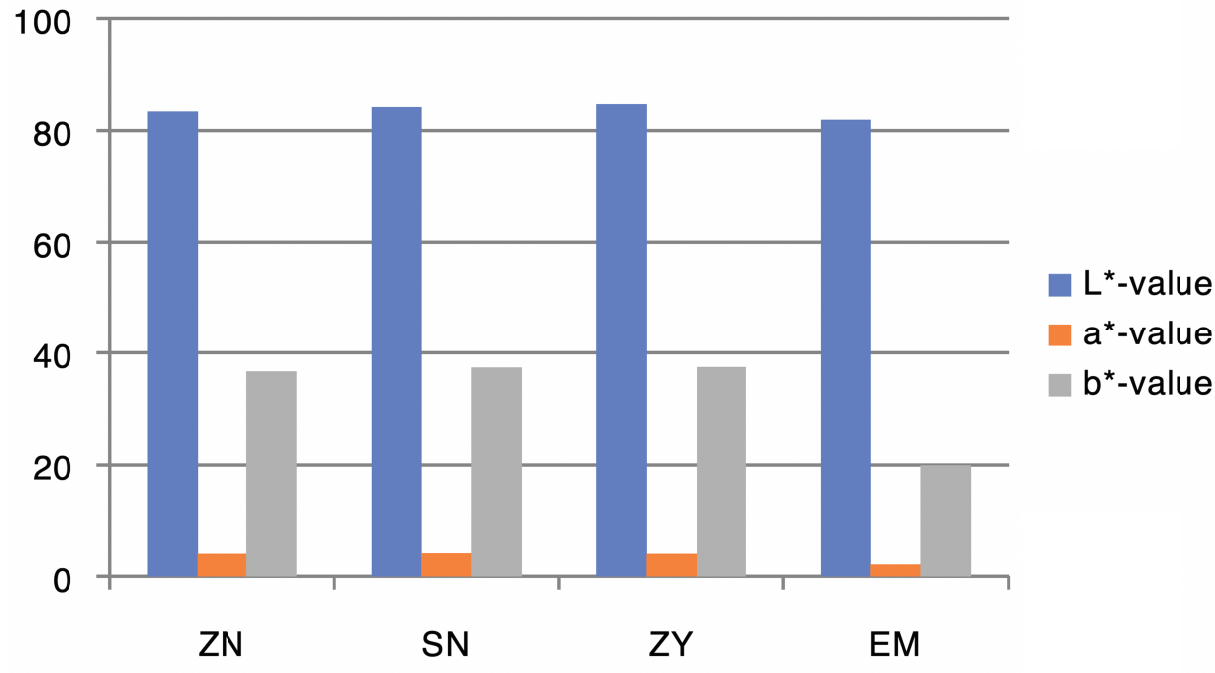

Figure 3. $L^{*}, a^{*}, b^{*}$ value of metal core groups and lithium disilicate glass ceramic group. ZN: ZEROY, ZY: ZEROY-Y, SN: StarLoy N, EM: IPS e.max Press.
Table 7. Mean values of $L^{*}, a^{*}, b^{*}$ opaque metal core groups

\begin{tabular}{lllll}
\hline $\begin{array}{l}\text { Veneering } \\
\text { materials }\end{array}$ & Group & L*-value & a*-value & b*-value \\
\hline Opaque A3 & ZNO & $12.23(0.40)$ & $7.59(0.18)$ & $16.50(0.18)$ \\
& SNO & $13.64(0.21)$ & $6.88(0.22)$ & $14.99(0.14)$ \\
& ZYO & $12.57(0.36)$ & $7.39(0.69)$ & $16.53(0.09)$ \\
\hline
\end{tabular}

ZN: ZEROY, ZY: ZEROY-Y, SN: StarLoy N, O: Opaque A3.

며, $\Delta \mathrm{E}^{*}$ 값의 경우 하부 구조에 따라 3 이상의 색차값을 보였으며, 통계 적으로 유의하였다(Fig. 3).

Table 7은 금속 세라믹 실험군의 불투명 세라믹의 $\mathrm{L}^{*}, \mathrm{a}^{*}, \mathrm{~b}^{*}$ 측정값 을 표시하였다. Table 5는 상아질 세라믹 소성 후 측정값과 비교해 보 면 L* 이 많은 차이가 나고, 상아질 세라믹에 비해 적색과 황색에 가까 운 것을 알 수 있었다. Table 8은 금속 세라믹 실험군의 금속 하부 구조 물을 opaque 소성 후 각 그룹간 비교분석한 결과이다. 두 색간의 색차 인 $\Delta \mathrm{E}^{*}$ 값은 $\mathrm{ZYO}-\mathrm{ZNO}$ 그룹은 $0.10, \mathrm{ZYO}-\mathrm{SNO}$ 그룹은 1.74 , 그리 고 $\mathrm{ZNO}-\mathrm{SNO}$ 그룹은 1.68 값이 측정되었다. $\mathrm{ZYO}$ 와 $\mathrm{ZNO}$ 그룹 사이 에는 0.10 으로 색깔의 차이가 보이지 않았으나 $\mathrm{ZYO}$ 와 $\mathrm{ZNO}$ 를 $\mathrm{SNO}$ 그룹과 비교 분석했을 때 1.5 3.0 사이로 나타나 감지 할 수 있을 정도 의 차이로 관찰되었다.

\section{DISCUSSION}

금속 세라믹 시스템을 이용한 보철물 수복에서 자연치와 비슷한 색 조를 재현하는 것은 중요한 심미적 요소이다. 자연치아의 색조는 매우 다양하며, 동일 치아에서도 부위에 따라 다르고 치아의 위치나 연령에 따라서도 각각 다르기 때문이다.

일반적으로 치과에서 보철물의 정확한 색조를 선택하기 위해 색견본 (shade guide)과 환자의 치아를 눈으로 관찰하여 색조를 비교 분석하
Table 8. Mean $\Delta \mathrm{E}_{\text {ab }}$ values of specimens in combination metal core and opaque $A 3$ groups

\begin{tabular}{ccc}
\hline Veneering Materials & Between group & $\Delta$ E-value \\
\hline Opaque A3 & ZYO-ZNO & 0.10 \\
& ZYO-SNO & 1.74 \\
& ZNO-SNO & 1.68 \\
\hline
\end{tabular}

ZN: ZEROY, ZY: ZEROY-Y, SN: StarLoy N, O: Opaque A3.

는 직접적인 관찰법이 많이 사용되고 있으나, 이는 주관적이며 관찰하 는 조건이나 개인적, 심리적 차이에 따라 색 인식에 대해 많은 이견이 있어서 객관성을 유지하는데 어려움이 있다[12]. 색조에 대한 시각적 오차 없이 비교 분석하기 위한 방법으로 spectrometer와 같은 기기를 이용하는 객관적 측정법인 측색법과 색체계(color system)를 이용하는 방법이 있다. 색(color)을 객관적으로 표시하기 위한 방법으로 Munsell, RGB, 그리고 CIE 색체계가 대표적으로 많이 사용된다. Munsell 색체계는 가장 많이 알려진 방법으로 색을 색상(hue), 명도(value), 채도(chroma)로 표현하는 방법이고 RGB 색체계는 빨강(red), 초록 (green) 그리고, 파랑(blue)의 세 가지 색 빛으로 원하는 색상으로 표현 하는 방법으로 각색의 앞 글자에서 이름이 붙여졌다. CIE 표준 색체계 는 일명 XYZ 색체계로 알려져 있고, RGB 색체계의 기본 3색을 기준으 로 정량적인 수치 즉, 좌표로 나타낼 수 있는 색체계로 Adams 좌표계 라고 하며 각 축은 $\mathrm{L}^{*}, \mathrm{a}^{*}, \mathrm{~b}^{*}$ 로 나타낸다. $\mathrm{L}^{*}$ 은 명도 값을 나타내며, 가 장 밝은 수치를 100 으로, 가장 어두운 수치를 0 으로 나타낸다. $a^{*}$ 는 적 색채도를 나타내며, -60 에서 +60 값을 가지고, + 값은 적색, - 값은 보색 인 녹색을 나타낸다. $b^{*}$ 는 황색채도를 나타내며, $a^{*}$ 와 동일 한 범위에 서 +값은 황색, - 값은 보색인 청색의 값을 나타낸다[13].

본 연구의 선행연구에서는 금속 세라믹 시스템에서 $\mathrm{Ni}-\mathrm{Cr}$ 합금 성능 향상에 도움이 되었던 베릴륨의 생물학적 문제로 인한 사용 규제로, 세 라믹 소성시 발생되는 과도한 산화막등으로 인한 하부 금속 코어와 전 
장 세라믹의 박리(delamiantion) 현상과 최종 수복물 소성 후 발생되 는 황변 현상 등을 해결하기 위한 목적으로 $\mathrm{Ni}-\mathrm{Cr}$ 합금에 이트륨을 추 가하여 조성하고 이트륨 포함 여부에 따른 $\mathrm{Ni}-\mathrm{Cr}$ 합금과 전장 세라믹 간의 전단결합강도를 조사하였다. 선행연구의 결과로는 이트륨이 포함 된 $\mathrm{Ni}-\mathrm{Cr}$ 합금 실험군에서 이트륨이 포함되지 않은 군과 비교할 때 전 단결합강도의 증가가 통계적으로 유의한 차이로 관찰 되어 $\mathrm{Ni}-\mathrm{Cr}$ 합금 에 포함된 이트륨은 금속 산화물 생성에 영향을 미쳐 전장 세라믹과 하 부 금속 코어간의 화학적 결합력을 증가 시키는 것으로 사료되었다.

본 연구는 이트륨을 추가하여 조성한 $\mathrm{Ni}-\mathrm{Cr}$ 합금과 현재 임상에서 사용되고 있는 이트륨이 포함되지 않은 $\mathrm{Ni}-\mathrm{Cr}$ 합금 2종에 전장 세라 믹을 소성하고 색차계를 사용하여 최종 수복물의 색조를 평가한 후속 연구이다. 불투명 세라믹을 도포한 모든 실험군에서 $\Delta \mathrm{E}^{*}$ 값은 0.1 부터 1.68 의 분포로 나타났으며, 제조사가 다른 $\mathrm{Ni}-\mathrm{Cr}$ 합금 실험군 $\mathrm{ZYO}-$ $\mathrm{SNO}$ 에서 1.74 로 숙련된 전문가에 의해서만 구별이 가능한 정도로 나 타났고, 이트륨을 제외하고 $\mathrm{Ni}-\mathrm{Cr}$ 합금의 조성이 같은 $\mathrm{ZYO}-\mathrm{ZNO}$ 실 험군에서는 0.1 로 육안으로는 색 차이를 구별할 수 없는 것으로 관찰되 었다. 실험의 결과로 $\mathrm{Ni}-\mathrm{Cr}$ 합금의 조성이 같고 이트륨이 포함된 실험 군과 포함되지 않은 실험군에서는 세라믹 소성 후 색조의 차이가 나타 나지 않아 $\mathrm{Ni}-\mathrm{Cr}$ 합금에 포함된 이트륨 성분은 금속 세라믹 수복물의 색조에 영향을 미치지 않는다고 사료된다.

Seghi [14]는 CIE L* $\mathrm{a}^{*} \mathrm{~b}^{*}$ 값으로 계산된 $\Delta \mathrm{E}^{*}$ 값에 대한 연구에서 색 감각은 개인의 성향이나 주관적인 기준에 따라 영향을 받을 수 있으 나, 두 물체의 색 차이를 인지하는 능력은 근소한 색차이도 감지 할 수 있다고 하였다. 색 차이를 인지하는 능력은 전문가 집단과 일반인 집단 에 따라 차이가 있는데, 두 물체의 색 차이가 $\Delta \mathrm{E}^{*}<1$ 경우는 육안으로 색 차이를 구별할 수 없으며 기계적인 방법에 의해서 색 차이를 구별하 는 것이 가능하다. $1<\Delta \mathrm{E}^{*}<2$ 인 경우는 숙련된 전문가에 의해서만 구별 이 가능하며, $\Delta \mathrm{E}^{*}>2$ 인 경우는 일반인도 색 차이 구별이 가능하므로 두 물체간의 색 차이가 $\Delta \mathrm{E}^{*}<2$ 이하이면 임상적으로 받아들일 만하다고 하 였다. 미국치과의사협회 (American Dental Association)에서도 색 차이를 구별 할 수 있는 기준값으로 $\Delta \mathrm{E}^{*}$ 값 2 를 규정하고 있다[15]. 그 외에도 Johnston과 Kao [16]는 $\Delta \mathrm{E}^{*}$ 가 3.7 이하이면 치과용 수복재로 임상 적용이 가능하다고 하였으며, Crispin 등[17]은 $\Delta \mathrm{E}^{*}$ 값 2 를 육안 으로 식별 가능한 기준점으로 하여 2 이상인 경우는 식별 가능한 색 변 화가 있다고 하였고, $\mathrm{O}^{\prime} \mathrm{Brien}$ 등[18]은 $\Delta \mathrm{E}^{*}$ 가 1 이하일 경우 색일치 가 우수하고, 2 이하일 경우 임상적으로 허용 가능하며, 3.7 이상일 경 우 임상적으로 색 차이가 확연히 구별될 수 있다고 하였다

Vichi 등[19]의 연구에 따르면 전장 세라믹 두께가 $1.5 \mathrm{~mm}$ 이하인 경우 하부구조물의 색조가 중요한 역할을 한다고 하였고, Dozić 등[2] 은 불투명 세라믹과 전장 세라믹 두께 비율에 따른 심미성의 상관관계 를 보고하였다. 본 연구에서는 상아질 세라믹의 두께는 $1.2 \mathrm{~mm}$ 로 모 든 실험군에서 균일하게 소성하여 측정하였고 각 실험군들의 $\Delta \mathrm{E}^{*}$ 값 을 비교하였다. 상아질 세라믹을 소성한 실험군들에서 $\Delta \mathrm{E}^{*}$ 값은 0.12
부터 1.05 의 분포로 나타났으며 금속 세라믹 모든 실험군에서 색 일 치가 우수한 것으로 관찰되어 $\mathrm{Ni}-\mathrm{Cr}$ 합금에 포함된 이트륨은 최종 수 복물의 색조에 영향을 미치지 않은 것으로 사료된다. 반면, 금속 세라 믹 실험군과 리튬디실리케이트 실험군의 $\Delta \mathrm{E}^{*}$ 값은 분포도가 143.30 에서 159.29 로 관찰되어 매우 유의한 차이가 있었다. 이번 연구결과 에서 $\mathrm{Ni}-\mathrm{Cr}$ 합금 실험군에서 색견본 $\mathrm{A} 3$ 색상의 기준 명도 75.36보다 83.45 에서 84.68로 모두 밝은 $\mathrm{L}^{*}$ 값이 관찰되었는데. 그 이유는 불투명 세라믹과 금속 하부 구조물 때문인 것으로 생각되며[20], $\mathrm{a}^{*}$ 와 b* 측정 값은 색견본 $\mathrm{A} 3$ 색상에 비해 높게 나타났고 채도가 높다는 것을 의미 하는 것으로 자연치나 올세라믹 보철물과 비교해 보면 채도가 강하다 는 것을 알 수 있었다.

이번 연구에서는 임상적으로 사용되는 $\mathrm{Ni}-\mathrm{Cr}$ 합금에 이트륨을 추가 하여 합금을 조성하고 상아질 세라믹으로 한정하여 색상에 대한 비교 분석을 시행하였다. $\mathrm{Ni}-\mathrm{Cr}$ 합금을 사용한 금속 세라믹 시스템 실험군 들에서는 CIE L* $\mathrm{a}^{*} \mathrm{~b}^{*}$ 값은 유사하게 나타나 색상에 대한 차이는 없는 것으로 나타났고, 리튬디실리케이트 올세라믹 실험군과 비교하면 명도 $\mathrm{L}^{*}$ 값은 차이가 나지 않았으나 $\mathrm{a}^{*} \mathrm{~b}^{*}$ 값은 높게 나타나 자연치 색상에 비해 채도가 높고 적색과 황색에 가까운 것으로 나타났다.

앞으로 임상에서 $\mathrm{Ni}-\mathrm{Cr}$ 합금의 더 나은 전장 세라믹과의 결합강도 증가와 자연치에 가까운 최종 수복물의 색조 향상을 위해 다양한 합금 의 성분들을 추가하여 합금을 조성하고 전장 세라믹과 열팽창계수 등 을 고려한 전장 세라믹의 선택이나 객관적인 측색 방법에 대한 연구가 필요하리라 사료된다.

\section{CONCLUSIONS}

본 연구에서는 시판되고 있는 $\mathrm{Ni}-\mathrm{Cr}$ 합금의 성분에 이트륨을 추가하 여 조성하고 CIE L* a* b* 색체계로 환산하는 분광측색기를 이용하여 조성을 달리한 세라믹 전장용 $\mathrm{Ni}-\mathrm{Cr}$ 계 합금에 따라 전장 세라믹 색조 에 미치는 차이를 조사하여 다음과 같은 결론을 얻었다.

1. 이트륨이 포함된 $\mathrm{Ni}-\mathrm{Cr}$ 합금에 불투명 세라믹 도포 후 각 실험군 의 $\Delta \mathrm{E}^{*}$ 값은 2 이하로 색 차이를 육안으로 구별하기 어렵다.

2. 상아질 세라믹 소성 후 금속 세라믹 실험군의 $\Delta \mathrm{E}^{*}$ 값은 1 이하로 색 일치도가 우수하였다.

3. 금속 하부구조물과 불투명 세라믹의 영향으로 $\mathrm{a}^{*} \mathrm{~b}^{*}$ 값은 높게 나 타났고 자연치 색상에 비해 채도가 높았다.

4. 모든 실험군에서 명도는 자연치 색견본 명도와 유사하였다.

\section{ACKNOWLEDGEMENTS}

본 연구는 김사임(2019)의 남부대학교 석사학위논문 ‘치과용 $\mathrm{Ni}-\mathrm{Cr}$ 합금의 조성에 따른 세라믹의 색차 분석'에서 발췌하여 정리하였다. 


\section{ORCID}

Sa-Im Kim, https://orcid.org/0000-0002-9196-8441

Tae-Yeon Kim, https://orcid.org/0000-0002-5907-419X

Se-Ha Kim, https://orcid.org/0000-0003-0305-1420

Jeong-Gyu Kang, https://orcid.org/0000-0003-1541-4997

Jung-Hwan Lee, https://orcid.org/0000-0002-2065-5632

\section{REFERENCES}

1. Azer SS, Ayash GM, Johnston WM, Khalil MF, Rosenstiel SF. Effect of esthetic core shades on the final color of IPS Empress all-ceramic crowns. J Prosthet Dent. 2006;96:397-401.

2. Kanitkar AA, Kanitkar AS, Sasane RS, Patil SS, Chopade SR, Vaidya S. Analyse the effect of different investment techniques and pattern materials on surface roughness of raw Ni-Cr castings - An In Vitro study. J Indian Prosthodont Soc. 2020;20:97-103.

3. Jeong SJ, Cho HW, Jung JH, Kim JM, Kim YL. Comparative evaluation of marginal and internal fit of metal copings fabricated by various CAD/CAM methods. J Korean Acad Prosthodont. 2019;57:211-218.

4. Revilla-León M, Sadeghpour M, Özcan M. A review of the applications of additive manufacturing technologies used to fabricate metals in implant dentistry. J Prosthodont. 2020;29:579-593.

5. Santos CD, Habibe AF, Simba BG, Lins JFC, Freitas BX, Nunes CA. CoCrMo-base alloys for dental applications obtained by selective laser melting (SLM) and CAD/CAM milling. Mat Res. 2020;23:e20190599.

6. Dozić A, Kleverlaan CJ, Meegdes M, van der Zel J, Feilzer AJ. The influence of porcelain layer thickness on the final shade of ceramic restorations. J Prosthet Dent. 2003;90:563-570.

7. Jalali H, Alizadeh ES, Sadighpour L, Shabestari GO, Fard MJ. The effect of background and ceramic thickness on the color of an all-ceramic restorative system. J Calif Dent Assoc. 2010;38:179-186.
8. Corciolani G, Vichi A, Louca C, Ferrari M. Influence of layering thickness on the color parameters of a ceramic system. Dent Mater. 2010;26:737-742.

9. Stevenson B, Ibbetson R. The effect of the substructure on the colour of samples/restorations veneered with ceramic: a literature review. J Dent. 2010;38:361-368.

10. Luthardt RG, Holzhüter M, Sandkuhl O, Herold V, Schnapp JD, Kuhlisch E, et al. Reliability and properties of ground Y-TZP-zirconia ceramics. J Dent Res. 2002;81:487-491.

11. Kelly JR, Nishimura I, Campbell SD. Ceramics in dentistry: historical roots and current perspectives. J Prosthet Dent. 1996;75:18-32.

12. Kim CS, Lim JS, Jeong CM, Jeon YC. Colorimetric analysis of color differences between dentin porcelains. J Korean Acad Prosthodont. 1999;37:425-432.

13. Saleski CG. Color, light, and shade matching. J Prosthet Dent. 1972;27:263-268.

14. Seghi RR. Effects of instrument-measuring geometry on colorimetric assessments of dental porcelains. J Dent Res. 1990;69:1180-1183.

15. Wozniak WT. In: Proposed guidelines for the acceptance program for dental shade guides. American Dental Association. Chicago. 1987.

16. Johnston WM, Kao EC. Assessment of appearance match by visual observation and clinical colorimetry. J Dent Res. 1989;68:819-822.

17. Crispin BJ, Jo YH, Hobo S. Esthetic ceramic restorative materials and techniques. In: Crispin BJ, ed. Contemporary esthetic dentistry: practice fundamentals. Chicago (IL): Quintessence Publishing, 1994. p. 155-188.

18. O'Brien WJ, Groh CL, Boenke KM. A new, small-colordifference equation for dental shades. J Dent Res. 1990;69:1762-1764.

19. Vichi A, Ferrari M, Davidson CL. Influence of ceramic and cement thickness on the masking of various types of opaque posts. J Prosthet Dent. 2000;83:412-417.

20. Barghi N, Lorenzana RE. Optimum thickness of opaque and body porcelain. J Prosthet Dent. 1982;48:429-431. 